\title{
EFEKTIFITAS PENGHUKUMAN BAGI PELAKU MAISIR (PERJUDIAN) DI KOTA LANGSA ${ }^{1}$
}

\author{
${ }^{1)}$ Siti Sahara, ${ }^{2)}$ Meta Suriyani \\ 1), 2) Dosen Fakultas Hukum Universitas Samudra, Meurandeh - Langsa- Aceh \\ sitisahara@unsam.ac.id | metasuriyani179@yahoo.com
}

\begin{abstract}
Qanun Aceh Number 6 of 2014 on Jinayat Law regulating maisir has the purpose of preventing and tackling maisir crime. Maisir is one of the criminal acts that disturb the public. The resulting consequences can disrupt public order and be felt by the families of the gambling players. Maisir often lead to other crimes such as liquor, theft, domestic violence, fights and so on. Penalties for gamblers in Langsa City have not been effective. The punishments under the prevailing laws and regulations include 'Uqubat Hudud and Takzir. However, there is a possibility that there are still obstacles that cause a deterrent effect only for the convict and partially people in Langsa City and did not close the possibility of always a new perpetrator and the absence of human resources from the WH capacity / competent as a PPNS so it can not be independent in enforcing law. This research uses empirical law research, that is by collecting data in the field through direct interviews with respondents and informants
\end{abstract}

Keywords: Effectiveness, Punishment, Maisir.

Abstrak, Qanun Aceh Nomor 6 Tahun 2014 tentang Hukum Jinayat mengatur tentang maisir mempunyai tujuan mencegah dan menanggulangi kejahatan maisir. Maisir merupakan salah satu tindak pidana yang meresahkan masyarakat. Akibat yang ditimbulkannya dapat mengganggu ketertiban masyarakat dan dirasakan oleh keluarga dari si pemain judi. Maisir kerap menimbulkan kejahatan lainnya seperti minuman-minuman keras, pencurian, kekerasan dalam rumah tangga, perkelahian dan lain sebagainya.Penghukuman bagi pelaku maisir (perjudian) di Kota Langsa belum efektif. Penghukuman berdasarkan peraturan perundang-undangan yang berlaku diantaranya 'Uqubat Hudud dan Takzir. Namun tidak menutup kemungkinan masih terdapat hambatan yaitu menimbulkan efek jera hanya bagi nara pidana dan sebahagian masyarakat di Kota Langsa dan tidak menutup kemungkinan selalu adanya pelaku baru dan belum adanya sumber daya manusia dari WH yang berkapasitas/kompeten sebagai PPNS sehingga belum dapat mandiri dalam melakukan penegakan hukum. Penelitian ini mengunakan penelitian hukum empiris, yaitu dengan cara mengumpulkan data data di lapangan melalui wawancara langsung dengan responden dan informan.

Kata Kunci : Efektifitas, Penghukuman, Maisir.

\section{Pendahuluan}

Sepanjang perjalanan bernegara, Indonesia sampai saat ini telah memiliki 34 Provinsi dengan keanekaragaman suku dan adat - istiadat. Negara Indonesia sangat memperhatikan segala sesuatu yang ada dan tumbuh dalam kehidupan masyarakatnya sebagai suatu gejala sosial terutama masalah agama, kepercayaan dan adat-istiadat. Sehingga perlu mengaturnya dalam peraturan dasar yaitu Undang-Undang Dasar

${ }^{1}$ Hasil Penelitian Dosen Pemula, DRPM KEMENRISTEKDIKTI TAHUN 2017 dengan Nomor Kontrak : 172.U/UN54.6/LT/2017. 
Republik Indonesia Tahun 1945. Dari 34 Provinsi yang dimiliki negara Indonesia, Aceh adalah salah satu Provinsi yang jika ditelaah sejarahnya, dari dahulu sampai sekarang sangat kental dengan adat-istiadat dan agamanya serta sangat antusias ingin melaksanakan syariat Islam secara kaffah.

Islam telah mewarnai kehidupan di Aceh. Hal yang menarik Islam di Aceh bukan hanya sekedar agama ritual semata. Tetapi lebih dari itu, Islam juga menjadi kekuatan yang besar yang tidak dapat dipisahkan dari adat. Bahkan menjadi ideology yang mendarah daging dan menyatu dalam kehidupan di Aceh. Seperti hadih maja (Pepatah) orang tua di Aceh sebagai berikut: Hukom meunyo hana adat tabeue, adat menyoe hana hukom bateue (hukum tanpa adat, hambar; adat tanpa hukum batal). ${ }^{2}$

Pepatah di atas, mencerminkan persepsi masyarakat Aceh dalam menempatkan posisi yang sama antara agama Islam dan adat. Adat merupakan seperangkat nilai norma kehidupan dan keyakinan sosial yang tumbuh dan berakar dalam kehidupan masyarakat. Sebagai tata kelakuan, adat merupakan kaedah-kaedah normatif yang diakui dan ditaati oleh warga masyarakat yang bersangkutan. Pada tataran praktis, pranata adat dan agama di Aceh saling berkaitan dan berjalan seiring saling memperkuat satu sama lainnya .

Pranata adat dan agama di Aceh demi untuk cita-cita melaksanakan syariat islam secara kaffah, telah menciptakan produk hukumnya sendiri. Terbentuknya produk hukum tersebut didasarkan pada Al-qur'an dan Hadist dan peraturan-peraturan negara yang membolehkannya terbentuk yaitu Undang-Undang Nomor 22 Tahun 1999 telah diganti dengan Undang-Undang Nomor 32 Tahun 2004 tentang Pemerintahan Daerah, terakhir telah diganti pula dengan Undang-Undang Nomor 23 Tahun 2014 tentangPemerintahan Daerah. Undang-Undang Nomor 44 Tahun 1999 tentang Penyelenggaraan Keistimewaan Di Provinsi Daerah Istimewa Aceh yang kemudian pada tahun 2001, ketika diberikan otonomi daerah pada semua daerah di Indonesia, maka Aceh diberikan otonomi khusus melalui Undang-undang Nomor 18 Tahun 2001 dan lebih diperluas kewenangan melaksanakan otonomi melalui Undang-Undang Nomor 11 Tahun 2006 tentang Pemerintahan Aceh. Pemerintahan Aceh pada masa itu dibawah pimpinan Gubernur Abdullah Puteh. Beliau mendeklarasikan pemberlakuan syariat Islam di Aceh di Masjid Raya Baiturrahman Banda Aceh. ${ }^{3}$

Sebagai simbol dukungan rakyat Aceh pada program pelaksanaan syariat Islam tersebut, Qanun-qanun pun lahir melalui proses legislasi di Dewan Perwakilan Rakyat Aceh(DPRA). Selayaknya peraturan daerah lain, Qanun ini yang kemudian menjadi hukum materil dan formil syariat Islam di Aceh. Pada dasarnya Qanun-qanun yang diciptakan diinginkan berisikan formalisasi hukum fiqih Islam secara keseluruhan. Namun tidak semua ketentuan yang ada dalam fiqih Islam dapat menjadi Qanun Syariat Islam di Aceh. Pemilihannya disesuaikan dengan konteks dan kepentingan Aceh dan hukum nasional. Demikian juga beberapa hukum yang ada dalam fiqh Islam disesuaikan dengan perkembangan masyarakat di Aceh.

\footnotetext{
${ }^{2}$ Rusjdi Ali Muhammad dan Dedy Sumardi, Kearifan Tradisional Lokal Penyerapan Syariat Islam Dalam Hukum Adat Aceh, (Banda Aceh : Dinas Syariat Islam Aceh, 2011), hlm 37.

${ }^{3} \mathrm{http} / /$ kippas.wordpress.com/2007/06/04/euforia-pers-terhadap penerapan-syariat-islam/ di akses tangga 20Mei 2016.
} 
Pemerintah Aceh membuat aturan yang dapat mengatur rakyatnya dengan lebih baik, salah satunya seperti dinyatakan diatas adalah Qanun Aceh Nomor 13 Tahun 2003 tentang Maisir, dimana saat ini sudah tidak berlaku lagi telah diubah / digantidengan Qanun Aceh Nomor 6 Tahun 2014 tentang Hukum Jinayat. Salah satu tujuan keluarnya Qanun Hukum Jinayat yang mengatur tentang Maisir ini adalah untuk mencegah dan menanggulangi, artinya menjadikan kepada keadaan semula dan menghilangkan kejahatan maisir karena maisir merupakan salah satu tindak pidana sangat yang meresahkan masyarakat. Akibat yang ditimbulkannya bukan saja mengganggu ketertiban di masyarakat, tetapi akibatnya juga sangat dirasakan oleh keluarga dari si pemain judi. Maisir kerap menimbulkan kejahatan-kejahatan lainnya seperti minuman-minuman keras, pencurian, kekerasan dalam rumah tangga, perkelahian dan lain sebagainya.

Al-maisir berasal dari bahasa arab yasara atau yusr adalah mudah; atau yasar adalah kekayaan. Jadi Al-maisir adalah suatu bentuk permainan yang mengandung unsur taruhan dan orang yang menang dalam permainan itu berhak mendapat taruhan tersebut. ${ }^{4}$ Kamus Hukum juga mendefinisikan Judi adalah permainan dengan memakai uang sebagai taruhan seperti main dadu, kartu dan sebagainnya. Judi dapat juga bermakna mempertaruhkan sejumlah uang atau harta dalam permainan tebakan berdasarkan kebetulan, dengan tujuan mendapatkan sejumlah uang atau harta yang lebih besar dari jumlah uang atau harta semula. Sedangkan judi buntut adalah perjudian liar dengan cara menebak nomor akhir dari undian resmi. ${ }^{5}$

Menurut Qanun Hukum Jinayat, Maisir(perjudian) adalah perbuatan yang mengandung unsur taruhandan/atau unsur untung-untungan yang dilakukan antara 2(dua) pihak atau lebih, disertai kesepakatan bahwa pihakyang menang akan mendapat bayaran/keuntungan tertentudari pihak yang kalah baik secara langsung atau tidaklangsung. ${ }^{6}$ Pasal 303 ayat (3) Kitab Undang-Undang Hukum Pidana(KUHP) menyebutkan, yang dikatakan main judi adalah tiap-tiap permainan, yang mendasarkan pengharapan buat menang pada umumnya bergantung pada untung-untungan saja, dan juga kalau pengharapan itu jadi bertambah besar karena kepintaran dan kebiasaan pemain. Yang juga terhitung main judi ialah pertaruhan tentang keputusan perlombaan atau permainan lain, yang tidak diadakan oleh mereka yang turut berlomba atau bermain itu, demikian juga segala pertaruhan nyata.

Dalam Alquran Surat Almaidah, Allah berfirman yang artinya : Hai orang-orang yang beriman sesungguhnya arak,judi,berhala dan mengundi nasib adalah perbuatan keji termasuk perbuatan syaitan. maka jauhilah perbuatan-perbuatan itu agar kamu mendapat keberuntungan. sesungguhnya syaitan itu bermaksud menimbulkan permusuhan dan kebencian di antara kamu lantaran arak dan berjudi itu, menghalangi kamu dari mengingat Allah dan shalat; maka berhentilah kamu .(Q.S; Al-Maidah: 9091).

Sebenarnya kalau dinalar berjudi memang merugikan karena secara matematika peluang untuk menang berjudi itu sangat kecil, apalagi kalau pemainnya

\footnotetext{
${ }^{4}$ Abdul Azis Dahlan, Ensiklopedi Hukum Islam, (Jakarta : PT Ichtiar Baru van Hoeve, 1999), hlm. 1053.

${ }^{5}$ Sudarsono, Kamus Hukum, (Jakarta : Rineka Cipta, 2007), hlm 200.

${ }^{6}$ Lihat Pasal 1 angka (22) Qanun Aceh Nomor 6 Tahun 2014 tentang Hukum Jinayat.
} 
banyak. Memang banyak alasan logis dan ilmiah di balik larangan maupun anjuran dalam agama Islam. Allah SWT telah memperingatkan dengan tegas mengenai bahaya judi ini di dalam surat Al-Maidah ayat 90 - 91 yang telah disebutkan diatas, Kemudian Allah Swt berfirman Dalam Surat Al Maidah ayat 2 yang artinya “.....Dan tolong menolonglah kamu dalam (mengerjakan) kebajikan dan takwa, dan jangan tolong-menolong dalam berbuat dosa dan pelanggaran. Dan bertakwalah kamu kepada Allah, sesungguhnya Allah amat berat siksa-Nya."

Pengertian-pengertian diatas dapat dijadikan sebagai dasar untuk mengetahui apa itu Maisir (perjudian). Karena maisir (perjudian) ini, adalah salah satu tindakan kriminal. Tindakan kriminal yang dimaksud adalah tindakan-tindakan melawan peraturan perundang-undangan yang bersumber dari Al-Quran dan Hadist. ${ }^{7}$ Dengan ikutnya seseorang bermain judi maka ia juga ikut berperan aktif dalam meramaikan perjudian itu sendiri. Dan Sarat suatu hal dikatakan sebagai sebuah judi menurut agama adalah :

1. adanya harta yang dipertaruhkan.

2. adanya suatu permainan yang digunakan untuk menentukan pihak yang menang dan pihak yang kalah.

3. pihak yang menang akan mengambil harta (yang menjadi taruhan) dari pihak yang kalah (kehilangan hartanya).

Dalam Qanun Aceh Nomor 6 Tahun 2014 tentang Hukum Jinayat, ditegaskan, setiap orang yang dengan sengaja melakukan Jarimah Maisir dengan nilai taruhan dan/atau keuntungan paling banyak 2 (dua) gram emas murni, diancam dengan 'Uqubat Ta'zir cambuk paling banyak 12 (dua belas) kali atau denda paling banyak 120 (seratus dua puluh) gram emas murni atau penjara paling lama 12 (dua belas) bulan. Melakukan Jarimah Maisir dengan nilai taruhan dan/atau keuntungan lebih dari 2 (dua) gram emas murni, diancam dengan 'Uqubat Ta'zir cambuk paling banyak 30 (tiga puluh) kali atau denda paling banyak 300 (tiga ratus) gram emas murni atau penjara paling lama 30 (tiga puluh) bulan. Menyelenggarakan, menyediakan fasilitas, atau membiayai Jarimah Maisir diancam dengan 'Uqubat Ta'zir cambuk paling banyak 45 (empat puluh lima) kali dan/atau denda paling banyak 450 (empat ratus lima puluh) gram emas murni dan/atau penjara paling lama 45 (empat puluh lima) bulan. Melakukan Jarimah Maisir, dengan mengikutsertakan anak-anak diancam dengan 'Uqubat Ta'zir cambuk paling banyak 45 (empat puluh lima) kali atau denda paling banyak 450 (empat ratus lima puluh) gram emas murni atau penjara paling lama 45 (empat puluh lima) bulan. Melakukan percobaan Jarimah Maisir dikenakan 'Uqubat Ta'zir paling banyak 1/2 (setengah) dari 'Uqubat yang diancamkan. ${ }^{8}$

Jarimah adalah perbuatan yang dilarang oleh Syariat Islamyang dalam Qanun ini diancam dengan 'Uqubat Hudud dan/atau Ta'zir. 'Uqubat adalah hukuman yang dapat dijatuhkan oleh hakimterhadap pelaku Jarimah. ${ }^{10} \mathrm{Hudud}$ adalah jenis 'Uqubat yang bentuk dan besarannyatelah ditentukan di dalam Qanun secara tegas. ${ }^{11}$ Ta'zir adalah jenis

\footnotetext{
${ }^{7}$ Zainuddin Ali, Hukum Pidana Islam, Cetakan I, (Jakarta : Sinar Grafika, 2007), hlm 1

${ }^{8}$ Lihat Pasal 19 - Pasal 22 Qanun Aceh Nomor 6 Tahun 2014 tentang Hukum Jinayat

${ }^{9}$ Lihat Pasal 1 angka 16 Qanun Aceh Nomor 6 Tahun 2014 tentang Hukum Jinayat

${ }^{10}$ Lihat Pasal 1 angka 17 Qanun Aceh Nomor 6 Tahun 2014 tentang Hukum Jinayat

${ }^{11}$ Lihat Pasal 1 angka 18 Qanun Aceh Nomor 6 Tahun 2014 tentang Hukum Jinayat
} 
'Uqubat yang telah ditentukan dalamqanun yang bentuknya bersifat pilihan dan besarannyadalam batas tertinggi dan/atau terendah. ${ }^{12}$ Sanksi 'Uqubat Hudud dan/atau Ta'zir terhadap setiap orang yang melakukan perbuatan maisir, nyatanya dirasakan belum memiliki maksimal efektif dalam pelaksanaanya. Dimana salah satunya masih belum menimbulkan efek jera secara maksimal bagi masyarakat di Kota Langsa.Walaupun sebenarnya telah menimbulkan efek moral yaitu malu dikarenakan pelaksanaan pukulan cambuk di depan umum. Namun efek malu tersebut belum memberikan efek jera kepada masyarakatsecara keseluruhan untuk tidak melakukan perbuatan maisir. Sehingga selalu saja ada pelaku-pelaku baru terhadap perbuatan maisir.

Berdasarkan uraian diatas, mencari, meneliti, dan mengetahui fakta tentang efektifitas penghukuman bagi pelaku maisir (perjudian) di Kota Langsa sangatlah penting dilakukan. Sehingga ditentukan beberapa rumusan masalah yaitu diantaranya: Bagaimana keefektifitasan penghukuman bagi pelaku maisir (perjudian) di Kota Langsa? Dan, apa hambatan terhadap penghukuman bagi pelaku maisir (perjudian) di Kota Langsa?

\section{Metode Penelitian}

Jenis penelitian yang digunakan dalam penulisan ini adalah penelitian yuridis normatif dan empiris. Penelitian yuridis normatif adalah penelitian yang dilakukan dengan cara meneliti bahan pustaka atau data sekunder. Penelitian yuridis normatif adalah mencakup terhadap azaz-azaz hukum, sistematik hukum, perbandingan hukum dan sejarah hukum. ${ }^{13}$ Penelitian yuridis normatif adalah penelitian yang menggunakan data sekunder. ${ }^{14}$ Penelitian empiris adalah penelitian yang mencari data primer melalui studi lapangan dengan cara wawancara, observasi dan lainnya.

Data yang diperoleh, baik hasil penelitian lapangan maupun kepustakaan akan di analisis dengan menggunakan pendekatan kualitatif, yaitu suatu analisis yang menghasilkan data deskriptif, dan apa yang dinyatakan oleh responden dan informan secara tertulis maupun lisan dipelajari dan di teliti sebagai suatu yang utuh.Penelitian secara kualitatif didasarkan pada asumsi tentang realitas atau fenomena yang bersifat komplek. Dimana terdapat regularitas pada pola tertentu dengan penuh keragaman analisis data secara kualitatif dilakukan terhadap data primer dan sekunder yang berasal dari bahan hukum primer, bahan hukum sekunder dan bahan hukum tertier. ${ }^{15}$

\section{Pembahasan}

\section{Efektifitas penghukuman bagi pelaku maisir (perjudian) di Kota Langsa}

Dalam Ensiklopedi Hukum Islam dijelaskan bahwa yang dikatakan maisir atau cara melakukan maisir yaitu dimulai pada masa Jahilliah dikenal dua bentuk al-maisir, yaitu al-mukhatarah dan at-tajzi'ah. Dalam bentuk al-mukhatarah, dua orang laki-laki

\footnotetext{
${ }^{12}$ Lihat Pasal 1 angka 19 Qanun Aceh Nomor 6 Tahun 2014 tentang Hukum Jinayat

${ }^{13}$ Zainuddin Ali, Hukum Pidana Islam ... Op., Cit, halaman 14

${ }^{14}$ Zainuddin Ali, Hukum Pidana Islam ... Ibid, halaman 12

15 Burban Bungi, Analisis Data Penelitian Kualitatif, Pemahaman Filosofis Dan Metodologis Kearah Penguasaan Aplikasi, (Jakarta : Raja Gravindo Persada, Jakarta, 2003), hlm. 53
} 
atau lebih menempatkan harta dan istri mereka masing-masing sebagai taruhan dalam suatu permainan. Orang berhasil memenangkan permainan itu berhak mengambil harta dan istri dari pihak yang kalah. Harta yang sudah menjadi milik pemenang itu dapat diperlakukannya sekehendak hatinya. Jika dia menyukai kecantikan perempuan itu, dia akan mengawininya, namun jika dia tidak menyukainya, perempuan itu diambilnya sebagai budak atau gundik. Bentuk ini diriwayatkan oleh Ibnu Abbas. ${ }^{16}$

Dalam bentuk at-tajzi'ah, seperti dikemukakan oleh imam al-Qurtubi, permainannya adalah sebagai berikut. Sebanyak 10 orang laki-laki bermain kartu yang terbuat dari potongan-potongan kayu (karena ketika itu belum ada kertas). Kartu yang disebut al-azlam atau al-aqlam itu berjumlah sepuluh buah, yaitu al-faz berisi satu bagian, at-tau'am dua bagian, ar-raqib tiga bagian, al-halis empat bagian, an-nafis lima bagian, al-musbil enam bagian dan al-mu'alli berisi tujuh bagian, yang merupakan bagian terbanyak. Sedang kartu as-safih, al-manih, dan al-wagd merupakan kartu kosong. Jadi jumlah keseluruhan dari 10 nama kartu tersebut adalah 28 buah. Kemudian seeokor unta dipotong menjadi 28 bagian sesuai dengan jumlah isi kartu tersebut. Selanjutnya kartu dengan nama-nama sebanyak 10 buah itu dimasukan kedalam sebuah karung dan diserahkan kepada seseorang yang dipercaya. Kartu itu kemudian dikocok dan dikeluarkan satu-persatu sampai habis. Setiap peserta mengambil bagian dari unta itu sesuai dengan isi atau bagian yang tercantum dalam kartu tersebut. Mereka yang mendapat kartu kosong yaitu, tiga orang sesuai dengan jumlah kartu kosong, dinyatakan sebagai pihak yang kalah dan merekalah yang harus membayar unta tersebut. Sedangkan mereka yang menang, sedikit pun tidak mengambil daging unta, hasil kemenangan itu, melainkan seluruhnya dibagi-bagikan kepada orang miskin. ${ }^{17}$

Mereka yang menang saling membanggakan diri dan membawa-bawa serta melibatkan pula suku atau kabilah mereka masing-masing. Disamping itu, mereka juga menghina dan mengejek pihak yang kalah dengan menyebut-nyebut dan melibatkan kabilah mereka. Tindakan mereka selalu berakhir dengan perselisihan, percekcokan, bahkan saling membunuh dalam peperangan. Dari dua bentuk al-maisir tersebut dapat dipahami bahwa unsur penting lainnya dari permainan yang disebut al-maisir ini adalah bahwa permainan itu dilakukan secara langsung atau berhadap-hadapan tanpa perantara. Berdasarkan kenyataan ini, Ibrahim Hossen, seorang ulama fiqih asal Indonesia, berpendapat bahwa yang dimaksud dengan al-maisir itu adalah permainan yang mengandung unsur taruhan yang dilakukan oleh dua orang atau lebih secara langsung atau berhadap-hadapan dalam suatu majelis(tempat).

Dalam Al-Quran, kata al-maisir disebutkan sebanyak tiga kali, yaitu dalam surah Al-Baqarah jus 2 ayat 219 dan surah Al-Maidah jus 5 ayat 90 dan 91. Ketiga ayat ini menyebutkan beberapa kebiasaan buruk yang berkembang pada masa jahiliah, yaitu khamar(minuman), al-Maisir, ansab (berkorban untuk berhala), dan azlam (mengundi nasib dengan menggunakan panah). Dalam surah Al-Baqarah ayat 219, Allah SWT menjelaskan bahwa khamar dal al-maisir mengandung dosa besar dan juga beberapa manfaat bagi manusia. Akan tetapi, dosanya lebih besar dari pada manfaatnya. Manfaat

\footnotetext{
${ }^{16}$ Abdul Azis Dahlan, Abdul Azis Dahlan, Ensiklopedi Hukum Islam ... Op.cit, hlm 1053 ${ }^{17}$ Ibid
} 
yang dimaksud oleh ayat ini, khusus mengenai al-maisir, adalah manfaat yang hanya dinikmati oleh pihak yang menang. Pada bentuk permainan mukhatarah pihak yang menang dapat memperoleh harta kekayaan yang dijadikan taruhan dengan mudah dan dapat juga menyalurkan nafsu biologisnya dengan istri dari pihak yang kalah yang juga dijadikan sebagai taruhan. Sedangkan pada bentuk at-tajziah, pihak yang menang merasa bangga dan orang-orang miskin juga dapat menikmati daging unta yang dijadikan taruhan tersebut. Akan tetapi, al-maisir itu sendiri dipandang sebagai salah satu diantara dosadosa besar yang dilarang oleh agama Islam. ${ }^{18}$

Kemudian disini juga di jelaskan status hukum bermain lotre, Muhammad Abduh seorang tokoh pembaharuan pemikiran Islam dari Mesir mengemukakan pendapatnya tentang al-yanasib atau lotre, dalam kitab tafsir al-Manar juz II dengan sub judul "almaisir al-Yanasib"(judu lotre). Menurut al-yanasib adalah nama bagi kegiatan mengumpulkan uang dalam jumlah besar yang dilakukan oleh pemerintah, yayasan, atau organisasi dari ribuan orang. Sebahagian kecil dari uang yang terkumpul itu diberikan kembali kepada beberapa orang pemberi uang(penyumbang) tersebut. Setiap orang misalnya, mendapat 10\% dan dibagikan melalui cara al-maisir (cara berlaku pada permainan judi), sedang sisanya dikuasai oleh penyelenggara dan digunakan untuk kepentingan umum. Caranya adalah dengan mencetak kartu atau kupon yang disebut "kupon lotre" ini diual dengan harga tertentu dan diberi nomor dengan angka-angka tertentu serta dicantumkan pula jumlah uang yang akan diterima oleh pembelinya jika ia beruntung. ${ }^{19}$

Penentuan atas pemenang di antara pembeli kupon dilakukan melalui undian beberapa kali putaran. Para pembeli yang nomornya cocok dengan nomor yang keluar dalam undian dinyatakan sebagai pemenang dan berhak mendapatkan hadiah uang sebanyak $10 \%$ dari hasil yang terkumpul. Undian ini dilaksanakan secara periodik, misalnya sekali dalam sebulan dan waktunya sudah ditentukan. Sedangkan para pembeli kupon yang lain tidak mendapatkan apa-apa. Cara penetapan pemenang ini, menurut Abduh, mirip sekali dengan cara penentuan pemenang pada al-maisir bentuk at-tajzi'ah.

Dalam pandangan Abduh, al-maisir al-yanasib ini dengan jenis-jenis al-maisir yang lain tidak menimbulkan rasa permusuhan, kebencian, dan tidak menghalangi pelakunya dari perbuatan mengingat Allah SWT dan mendirikan shalat. Para pembeli kupon lotre itu tidak terkumpul pada satu tempat, tetapi mereka berada ditempat-tempat yang berjauhan jaraknya dengan pelaksanaan undian itu. Untuk mengikuti undian itu, mereka tidak banyak melakukan kegiatan lain yang menjauhkan mereka dari zikir dan shalat, seperti yang berlaku pada al-maisir jahiliah atau judi meja. Para pembeli yang tidak beruntung juga tidak mengetahui orang yang memakan hartanya, berbeda dengan pelaksanaan al-maisir jahiliah atau judi meja. Akan tetapi, lanjut Abduh, dalam pelaksanaannya undian lotre ini terdapat akibat-akibat buruk seperti yang juga terdapat pada jenis judi lainnya. Akibat-akibat dimaksud antara lain adalah kenyataan bahwa pelaksanaan undian lotre ini merupakan salah satu cara untuk mendapatkan harta orang

\footnotetext{
${ }^{18}$ Ibid , hlm.1054

${ }^{19}$ Ibid, 1055
} 
lain secara tidak sah, yaitu tanpa adanya imbangan yang jelas, seperti pertukaran harta itu dengan benda lain atau dengan suatu jasa. Cara-cara seperti ini diharamkan oleh syarak. ${ }^{20}$

Selanjutnya taruhan yang dibenarkan. Dalam beberapa kitab fiqih dikemukakan beberapa bentuk taruhan yang dibenarkan dan tidak termasuk dalam kategori al-maisir. Diantaranya adalah sebagai berikut:

1. Barang yang dijadikan taruhan itu disediakan oleh pemerintah atau pihak ketiga, atau orang lain. Misalnya, pemerintah atau pihak ketiga tersebut berkata kepada dua orang atau lebih dalam suatu perlombaan (lomba) pacuan kuda: "siapa yang berhasil keluar sebagai pemenang akan diberi hadiah". Berdasarkan kriteria ini, maka perlombaanperlombaan olah raga yang diseponsori oleh pemerintah atau pihak ketiga dengan menyediakan hadiah-hadiah tertentu, baik berupa uang maupun penghargaan untuk para pemenang tidak termasuk kategori al-maisir.

2. Taruhan itu bersifat sepihak, yaitu berasal dari salah satu pihak yang ikut dalam perlombaan tersebut. Misalnya, seseorang yang berkata kepada temannya yang diajaknya bertanding dalam suatu perlombaan: "Jika kamu bisa mengalahkan saya, saya akan memberimu hadiah. Akan tetapi, jika kamu kalah tidak ada kewajiban apapun atas mu untuk saya." Kriteria ini dipahami dari hadis Rasulullah SAW yang diriwayatkan oleh Imam Abu Dawud. Dalam hadis itu disebutkan bahwa Rukanah, salah seorang kafir Kuraisy, pernah mengajak Rasulullah SAW untuk mengikuti permainan gulat dengannya. Dia menawarkan beberapa ekor kambing jika Rasulullah SAW menang. Dalam pertandingan itu, ternyata Rasulullah SAW menang dan Rukanah pun akhirnya masuk Islam. ${ }^{21}$

Dalil- dalil yang mengharam kan judi atau maisur Allah Ta'ala berfirman:

Dalil 1 : "Hai orang-orang yang beriman, sesungguhnya (meminum) khamar, berjudi, (berkorban untuk) berhala, mengundi nasib dengan panah, adalah termasuk perbuatan syaitan. Maka jauhilah perbuatan-perbuatan itu agar kamu mendapat keberuntungan" (QS. Al Maidah: 90).

Dalil 2: judi disebut dengan rijs (najis)Ar rijs artinya najis. Adapun ar rujz artinya dosa, dan semua yang mengandung bahaya. Allah terkadang menyebut berhala dengan rijs, seperti dalam firman-Nya: "maka jauhilah olehmu berhala-berhala yang najis itu” (QS. Al Hajj: 30).Dan terkadang Allah menyebutnya dengan rujz. “dan perbuatan dosa tinggalkanlah" (QS. Al Mudatsir: 5).

Dalil 3: judi adalah amalan setan. Allah Ta'ala berfirman: "Sesungguhnya syaitan itu adalah musuh bagimu, maka anggaplah ia musuh(mu), karena sesungguhnya syaitan-syaitan itu hanya mengajak golongannya supaya mereka menjadi penghuni neraka yang menyala-nyala" (QS. Fathir: 6).Dan Allah juga mengabarkan kepada kita bahwa setan telah memperdaya Nabi Adam dan Hawa sehingga mereka dikeluarkan dari surga. Dan setan bersumpah kepada Adam dan Hawa bahwa ia adalah pemberi nasehat, padahal ia pendusta. Allah Ta'ala berfirman: “(setan) bersumpah kepada keduanya: 'saya adalah pemberi nasehat kepada kalian berdua" (QS. Al A'raf: 21).Allah memberi kita peringatan terhadap musuh besar

${ }^{20}$ Ibid

${ }^{21}$ Ibid, hlm. 1055 
kita ini dalam firman-Nya: "Hai anak Adam, janganlah sekali-kali kamu dapat ditipu oleh syaitan sebagaimana ia telah mengeluarkan kedua ibu bapamu dari surga" (QS. Al A'raf: 27).

Dalil 4: Allah memerintahkan untuk menjauhi judi. Allah Ta'ala memerintahkan untuk menjauhi empat hal ini yaitu khamr, judi, al anshab dan al azlam. Dan al ijtinab itu lebih mendalam dari pada at tark. Karena al ijtinab itu artinya: jauhkan diri darinya, ini lebih mendalam dari pada mengatakan: tinggalkan ia. At tark tidak melazimkan penjauhan diri, sedangkan al ijtinab itu maknanya lebih dalam, karena artinya: tinggalkan dan jauhilah, pergilah ke arah yang jauh darinya. Dan judi termasuk dalam empat hal ini.Maka menjauh dari judi itu lebih selamat, sedangkan mendekat kepada perjudian itu biasanya menjadi sebab atau sarana terjerumusnya seseorang ke dalamnya. Oleh karena itu Allah memerintahkan kita untuk tajannub, yaitu menjauhinya. Maka janganlah kita mendekati tukang judi dan jangan berteman dengannya, jangan membersamainya, jangan bermuamalah dengannya, jangan mencintainya, jangan duduk bersama dengannya, serta jangan kasihan padanya. Bahkan seharusnya anda menjauh sejauh-jauhnya sehingga kehormatanmu, agamamu, akidahmu selamat. Karena kondisi agamamu berada dalam kekhawatiran jika anda mendekat dengan hal-hal tersebut, atau jika anda duduk bersama dengan tukang judim atau tukang minum khamr, dan semacamnya. Dan yang semisal mereka, dikhawatirkan akan mengotori kehormatanmu dan agamamu. Atau bisa jadi anda terjerumus ke dalamnya walaupun sedikit, atau engkau menyukai sesuatu dari hal-hal tersebut, atau semisalnya. Inilah sebabnya mengapa Allah Ta'ala memerintahkan kita untuk menjauhinya dalam firman-Nya (yang artinya): "Maka jauhilah perbuatan-perbuatan itu..".

Dalil 5: didapatkannya keberuntungan dengan menjauhi judi. Dalam firman Allah Ta'ala disebutkan: "semoga engkau beruntung". Al falah artinya kemenangan, keberhasilan, kebahagiaan di dunia dan akhirat, mendapatkan apa yang diinginkan, meraih apa yang diminta. Inilah al falah. Maka muflih adalah orang yang mendapatkan apa yang ia minta.Namun kapan anda mendapatkan al falah? Jawabnya yaitu ketika anda menjauhi empat perkara ini yang diantaranya: judi. Jika anda menjauhinya, menghindarinya, dan membenci pelakunya, maka anda termasuk muflihin, artinya semoga anda termasuk orang yang mendapatkan al falah. Sebab inilah yang dikaitkan oleh Allah Ta'ala dengan sifat al falah, yaitu menjauhi empat perkara tersebut, termasuk judi. Maka al falah bisa didapatkan dengan menjauhi judi, dan kebinasaan bisa menghampiri dengan mendekati judi, dan kehancuran akan terjadi jika melakukannya, kesesatan akan datang jika terusmenerus melakukannya. Maka tidak ragu lagi akan haramnya judi.

Dalil 6: judi menimbulkan permusuhan di antara manusia. Berdasarkan firman Allah Ta'ala:Sesungguhnya syaitan itu bermaksud hendak menimbulkan permusuhan dan kebencian di antara kamu (lantaran meminum khamar dan berjudi itu)" (QS. Al Maidah: 91). Maksudnya, setan bersemangat untuk menimbulkan permusuhan di antara manusia. Dan al 'adawah artinya: muqatha' ah (pemutusan), yakni antara sesama saudara seiman saling memutus hubungan. Atau antara dua sahabat saling memutus hubungan, atau saling membenci, atau saling 
memboikot. Maka persaudaraan pun putus, mereka saling memutus hubungan satu sama lain, saling menjauhi, saling mencela, dan mudah untuk meng-ghibah-i dan mencederai kehormatan saudaranya, menuduhnya dengan hal yang buruk. Semua ini terjadi karena sebab khamr dan judi. Allah Ta'ala berfirman (yang artinya) : "Sesungguhnya syaitan itu bermaksud hendak menimbulkan permusuhan dan kebencian di antara kamu (lantaran meminum khamar dan berjudi itu)“.

Dalil 7: judi menimbulkan kebencian di antara manusia. Allah Ta'ala telah memerintahkan kaum Muslimin untuk saling bersaudara dan saling mencintai, serta menghilangkan percekcokan dan kebencian yang ada di antara mereka. Allah juga memerintahkan kaum Muslimin untuk saling mengikat persaudaraan karena Allah telah menamai mereka semua sebagai Muslimin dan memberi mereka nikmat berupa persaudaraan karena agama. Allah Ta'ala berfirman: "Dan ingatlah akan nikmat Allah kepadamu ketika kamu dahulu (masa Jahiliyah) bermusuh-musuhan, maka Allah mempersatukan hatimu, lalu menjadilah kamu karena nikmat Allah, orang-orang yang bersaudara; dan kamu telah berada di tepi jurang neraka, lalu Allah menyelamatkan kamu dari padanya" (QS. Al Imran: 103).

Dalil 8: judi itu memalingkan orang dari dzikrullah. Berpalingnya orang dari dzikrullah, ini adalah dalil lain yang menunjukkan keharaman khamr dan judi. Yaitu dalam firman Allah Ta'ala : “..dan menghalangi kamu dari mengingat Allah.." (QS. Al Maidah: 91).Maka permainan setan ini mengandung mafsadah yang besar, yaitu ia memalingkan orang dari dzikrullah. Dan ini sudah terbukti di lapangan, orang yang memainkan permainan judi, bahkan walaupun tidak menggunakan taruhan, ia akan tersibukan dengannya dan menghabiskan waktu yang banyak serta sangat menikmati permainan tersebut. Mereka mengklaim hal itu untuk menyegarkan jiwa dan menyenangkan jiwa mereka. Mereka pun membuang-buang waktu padahal waktu dalam permainan ini. Maka dengan ini mereka berpaling dari dzikrullah dan menyibukkan diri dengan kelalaian dan permainan, hingga mereka lupa kepada Allah. "Mereka melupakan Allah, maka Allah pun melupakan mereka" (QS. At Taubah: 67).Kami katakan kepada mereka, yang lebih utama bagi kalian, daripada waktu kalian digunakan secara sia-sia, lebih baik digunakan untuk menyibukkan diri dengan dzikrullah. Kalian berdzikir kepada Allah, kalian bertadabbur, dan banyak perkara yang bisa kalian lakukan. Kalian bisa gunakan waktu kalian untuk hal-hal yang bermanfaat. Adapun permainan-permainan ini, tidak ada manfaatnya di dunia dan di akhirat. Ia hanya memalingkan kalian dari dzikrullah, dari berdoa kepada Allah, dari ibadah kepadaNya, dan membuat kalian lalai dan keras hati.

Dalil 9: judi melalaikan orang dari shalat. Judi melalaikan orang dari shalat, ini suatu hal yang sudah terbukti. Orang yang menghabiskan waktu mereka dengan permainan judi secara umum adalah orang-orang yang melalaikan shalat. Dan mereka juga lalai dari ibadah-ibadah yang lain. Jika mereka melakukan ibadah pun biasanya disertai lupa dan was-was. Dan mereka juga sering begadang sepanjang malam sehingga tertidur ketika waktu shalat subuh, dan juga mengerjakan shalat- 
shalat yang lain. Atau minimalnya mereka tidak melaksanakan shalat secara berjama'ah. Apakah ini tidak cukup untuk menunjukkan keharaman judi?

Dalil 10: adanya perintah Allah untuk berhenti dari judi. Allah Ta'ala berfirman: "lalu mengapa kalian tidak berhenti?" (QS. Al Maidah: 91).Ini adalah dalil yang jelas yang menunjukkan keharaman judi. Allah Ta'ala memerintahkan kita untuk berhenti dari perjudian. Al intiha (berhenti) maknanya mencakup meninggalkan sekaligus bertaubat darinya. Oleh karena itu, ketika ayat ini turun, para sahabat pun berkata: "sekarang juga kami berhenti.. kami berhenti..!'Maksudnya: kami telah berhenti dari minum khamr dan bermain judi serta perbuatan haram lainnya. Maka firman Allah (yang artinya): "lalu mengapa kalian tidak berhenti?" adalah gaya bahasa tanya yang bukan bermaksud bertanya namun menyuruh. Maka maknanya: "berhentilah!“, artinya: sampai kapan kalian tidak berhenti melakukannya? sampai kapan kalian terus-menerus melakukannya? tidakkah tiba bagi kalian waktunya untuk berhenti? tidakkah kalian merasakan kerusakannya? mengapa kalian tidak berhenti? Maka para sahabat pun menjawab: "sekarang juga kami berhenti." 22

Ada beberapa alasan mengapa maisir sangat dilarang dalam Islam:

1) Secara ekonomis, maisir dapat mengakibatkan kemiskinan, sebab jarang terjadi seseorang terus-menerus menang, yang paling banyak justru kekalahan.

2) Secara psikologis sebagaimana kata Al-qur'an, perjudian bisa menumbuhkan sikap penasaran dan permusushan, dan sikap ria, takabur, sombong pada pihak yang menang. Sedangkan pada pihak yang kalah dapat mengakibatkan stres, depresi, bahkan menyebabkan bunuh diri.

3) Sedangkan secara sosiologis, perjudian dapat merusak sendi-sendi kekeluargaan yang merupakan inti masyarakat. Perjudian juga menyebabkan konflik sosial seperti perceraian, pertengkaranbahkan bisa mengarah kepada tindak kriminal seperti pembunuhan dan sebagainya. ${ }^{23}$

Para ulama tidak hanya memberikan ketentuan hukum terhadap perbuatan judi akan tetapi menentukan hukuman bagi orang yang melakukan perbuatan berjudi di antaranya:

1. Tidak diterima persaksian orang yang berjudi

2. Diberikan hukum fisik berupa pukulan dan dihancurkan alat judinya.

3. Tidak boleh diberi ucapan salam ketika bertemu dengannya.

4. Pemain judi mendapatkan laknat dari Allah Swt.

5. Pemain judi secara syariat boleh diusir dari rumah tinggalnya.

6. Pemain judi dapat diberikan hukuman menurut hukum yang berlaku untuk memberi pelajaran.

7. Pemain judi dapat diambil alih hak penguasaan harta oleh penguasa yang sah untuk menyelamatkan harta dan keluarganya.

\footnotetext{
${ }^{22}$ Sumber: http://www.ibn-jebreen.com/books/1-26-1162-1103-27973.html

${ }^{23} \mathrm{Al}$ Yasa' Abu bakar \& Mahar Halim, Hukum Pidana Islam di Nanggro Aceh Darussalam, (Banda Aceh : Dinas syari'at Islam Provinsi NAD, 2006), hlm 75-76
} 
Berdasarkan uraian diatas walau maisir sangat dilarang dan banyak mudharatnya, namun dari zaman dahulu hingga zaman modern sekarang ini maisir masih tetap lestari dan dilestarikan oleh pihak-pihak yang gemar padanya. Bahkan perkembangan jenis / bentuk dari maisir itu sendiri telah berinovasi dari zaman-zaman kemunculannya. Sebagaimana hasil dari penelitian yang dilakukan baik melalui obeservasi dan wawancara pada Mahkamah Syar'iyah Langsa, diketahui di Kota Langsa jenis / bentuk sebagai alat untuk tidak pidana maisiryang dipakai oleh para pelaku maisir bermacam-macam bentuknya diantaranya :Kartu Joker, Kartu Domino, Game Online, Togel, Batu Domino, Sabung Ayam dan lainnya. Di Kota Langsa, Lokasi yang sering diketemukan atau penangkapan pelaku maisir dan masih tetap terus dilakukan pengawasan terhadap lokasi yang rawan tindak pidana maisir maupun lainnya diantaranya :
a. Sidodadi
b. Alur dua
c. Karang Anyar
d. Lengkong
e. Alur Pinang
f. Bukit Rata
g. Blang Pase
h. Alur Brawe.

Usia pelaku maisiryaitu dari 20 tahun sampai 60 tahun dan rata- rata pendidikan tingkat SD sampai dengan SMA. ${ }^{24}$ Pekerjaan pelaku tindak pidana maisir sebahagian besar adalah
a. Penganguran / belum bekerja
b. PNS
c. Wiraswasta
d. BHL
e. Pedagang
f. Nelayan
g. Tukang Becak
h. Pelajar
i. Mahasiswa
j. Mocok- Mocok.

Sebagian besar pekerjaan dari pelaku maisir di Kota Langsa adalah dari kalangan menengah ke bawah. Hal ini secara logika dapat dipahami bahwa pada umumnya pelaku maisir adalah orang-orang yang sedang mempertaruhkan nasib atau untung-untungan. Dimana jika menang akan mengambil manfaat berupa barang/uang yang menjadi taruhan sehingga akan menambah penghasilan. Keadaan ini disebabkan kebutuhan kehidupan yang mencekik, malas berusaha dan kurangnya rasa keimanan yang ada pada diri pelaku maisir tersebut.

Dalam hal penegakan hukum terhadap tindak pidana maisir, dapat disandarkan kapada teori sistem Lowrence M. Friedman, namun dikelompokan sehingga lebih dipersempit yaitu hukum mencakup tiga komponen sebagai berikut: 
1. Legal subtance (substansi hukum) : merupakan aturan-aturan, norma-norma dan pola prilaku nyata manusia yang berada dalam sistem itu termasuk produk yang dihasilkan oleh orang yang berada didalam sistem hukum itu, mencakup keputusan yang mereka keluarkan aturan baru yang mereka susun.

2. Legal Structure (struktur hukum); merupakan kerangka, bagian yang tetap bertahan, bagian yang memberikan semacam bentuk dan batasan terhadap keseluruhan instansiinstansi penegak hukum. Di indonesia yang merupakan struktur dari sistem hukum antara lain ; institusi atau penegak hukum seperti advokad, polisi, jaksa dan hakim.

3. Legal culture (budaya hukum); merupakan suasana pikiran sistem dan kekuatan social yang menentukan bagaimana hukum itu di gunakan, di hindari atau di salah gunakan oleh masyarakat.

Dalam realita kehidupan bermasyarakat, seringkali penerapan hukum tidak efektif sehingga wacana ini menjadi perbincangan menarik untuk di bahas dalam perspektif efektifitas hukum. Artinya benarkah hukum yang tidak efektif atau pelaksana hukumkah sesungguhnya yang berperan untuk mengefektifkan hukum itu?

Sebenarnya pada hakikatnya persoalan efektifitas hukum seperti yang diungkapkan Dr. Syamsuddin Pasamai, SH., MH., dalam bukunya Sosiologi dan Sosiologi Hukum, persoalan efektifitas hukum mempunyai hubungan yang sangat erat dengan persoalan penerapan, pelaksanaan dan penegakan hukum dalam masyarakat demi tercapainya tujuan hukum. Artinya hukum benar-benar berlaku secara filosofis, juridis dan sosiologis.

Faktor-faktor yang mempengaruhi efektifitas suatu penerapan hukum. Hal ini sejalan dengan apa yang diungkapkan Ishaq, SH., MHum., dalam bukunya Dasar-dasar Ilmu Hukum yang menyebutkan dalam proses penegakan hukum, ada faktor-faktor yang mempengaruhi dan mempunyai arti sehingga dampak positif dan negatifnya terletak pada isi faktor tersebut.

Menurut Soerjono Soekanto bahwa faktor tersebut ada lima, yaitu :

1. Hukumnya sendiri.

2. Penegak hukum.

3. Sarana dan fasilitas.

4. Masyarakat.

5. Kebudayaan.

\section{A. Faktor Hukum}

Dalam praktik penyelenggaraan hukum di lapangan ada kalanya terjadi pertentangan antara kepastian hukum dan keadilan, hal ini disebabkan oleh konsepsi keadilan merupakan suatu rumusan yang bersifat abstrak, sedangkan kepastian hukum merupakan suatu prosedur yang telah ditentukan secara normatif.

Justru itu, suatu kebijakan atau tindakan yang tidak sepenuhnya berdasar hukum merupakan sesuatu yang dapat dibenarkan sepanjang kebijakan atau tindakan itu tidak bertentangan dengan hukum. Maka pada hakikatnya penyelenggaraan hukum bukan hanya mencakup low enforcement saja, namun juga peace maintenance, karena penyelenggaraan hukum sesungguhnya merupakan proses penyerasian antara nilai kaedah dan pola perilaku nyata yang bertujuan untuk mencapai kedamaian. 
Dengan demikian, tidak berarti setiap permasalahan sosial hanya dapat diselesaikan dengan hukum yang tertulis, karena tidak mungkin ada peraturan perundang-undangan yang dapat mengatur seluruh tingkah laku manusia, yang isinya jelas bagi setiap warga masyarakat yang diaturnya dan serasi antara kebutuhan untuk menerapkan peraturan dengan fasilitas yang mendukungnya.

Pada hakikatnya, hukum itu mempunyai unsur-unsur antara lain hukum perundangundangan, hukum traktat, hukum yuridis, hukum adat, dan hukum ilmuwan atau doktrin. Secara ideal unsur-unsur itu harus harmonis, artinya tidak saling bertentangan baik secara vertikal maupun secara horizontal antara perundang-undangan yang satu dengan yang lainnya, bahasa yang dipergunakan harus jelas, sederhana, dan tepat karena isinya merupakan pesan kepada warga masyarakat yang terkena perundang-undangan itu.

Mengenai faktor hukum dalam hal ini dapat diambil contoh pada pasal 363 KUHP yang perumusan tindak pidananya hanya mencantumkan maksimumnya saja, yaitu 7 tahun penjara sehingga hakim untuk menentukan berat ringannya hukuman dimana ia dapat bergerak dalam batas-batas maksimal hukuman.

Oleh karena itu, tidak menutup kemungkinan hakim dalam menjatuhkan pidana terhadap pelaku kejahatan itu terlalu ringan, atau terlalu mencolok perbedaan antara tuntutan dengan pemidanaan yang dijatuhkan. Hal ini merupakan suatu penghambat dalam penegakan hukum tersebut.

\section{B. Faktor Penegakan Hukum}

Dalam berfungsinya hukum, mentalitas atau kepribadian petugas penegak hukum memainkan peranan penting, kalau peraturan sudah baik, tetapi kualitas petugas kurang baik, ada masalah. Oleh karena itu, salah satu kunci keberhasilan dalam penegakan hukum adalah mentalitas atau kepribadian penegak hukum dengan mengutip pendapat $\mathrm{J}$. E. Sahetapy yang mengatakan :"Dalam rangka penegakan hukum dan implementasi penegakan hukum bahwa penegakan keadilan tanpa kebenaran adalah suatu kebijakan. Penegakan kebenaran tanpa kejujuran adalah suatu kemunafikan. Dalam kerangka penegakan hukum oleh setiap lembaga penegakan hukum (inklusif manusianya) keadilan dan kebenaran harus dinyatakan, harus terasa dan terlihat, harus diaktualisasikan".

Di dalam konteks di atas yang menyangkut kepribadian dan mentalitas penegak hukum, bahwa selama ini ada kecenderungan yang kuat di kalangan masyarakat untuk mengartikan hukum sebagai petugas atau penegak hukum, artinya hukum diidentikkan dengan tingkah laku nyata petugas atau penegak hukum. Sayangnya dalam melaksanakan wewenangnya sering timbul persoalan karena sikap atau perlakuan yang dipandang melampaui wewenang atau perbuatan lainnya yang dianggap melunturkan citra dan wibawa penegak hukum, hal ini disebabkan oleh kualitas yang rendah dari aparat penegak hukum tersebut.

Hal ini dapat berakibat tidak memahami batas-batas kewenangan, karena kurang pemahaman terhadap hukum, sehingga terjadi penyalahgunaan wewenang dalam melakukan tugas penyidikan dan tugas kepolisian lainnya.

Masalah peningkatan kualitas ini merupakan salah satu kendala yang dialami diberbagai instansi, tetapi khusus bagi aparat yang melaksanakan tugas wewenangnya menyangkut hak asasi manusia (dalam hal ini aparat penegak hukum) seharusnya 
mendapat prioritas. Walaupun disadari bahwa dalam hal peningkatan mutu berkaitan erat dengan anggaran lainnya yang selama ini bagi Polri selalu kurang dan sangat minim.

\section{Faktor Sarana atau Fasilitas Pendukung}

Faktor sarana atau fasilitas pendukung mencakup perangkat lunak dan perangkat keras, salah satu contoh perangkat lunak adalah pendidikan. Pendidikan yang diterima oleh Polisi dewasa ini cenderung pada hal-hal yang praktis konvensional, sehingga dalam banyak hal polisi mengalami hambatan di dalam tujuannya, diantaranya adalah pengetahuan tentang kejahatan computer, dalam tindak pidana khusus yang selama ini masih diberikan wewenang kepada jaksa, hal tersebut karena secara teknis yuridis polisi dianggap belum mampu dan belum siap. Walaupun disadari pula bahwa tugas yang harus diemban oleh polisi begitu luas dan banyak.

Masalah perangkat keras dalam hal ini adalah sarana fisik yang berfungsi sebagai faktor pendukung. Sebab apabila sarana fisik seperti kertas tidak ada dan karbon kurang cukup dan mesin tik yang kurang baik, bagaimana petugas dapat membuat berita acara mengenai suatu kejahatan. Menurut Soerjono Soekanto dan Mustafa Abdullah pernah mengemukakan bahwa bagaimana polisi dapat bekerja dengan baik, apabila tidak dilengkapi dengan kendaraan dan alat-alat komunikasi yang proporsional ?

Oleh karena itu, sarana atau fasilitas mempunyai peranan yang sangat penting di dalam penegakan hukum. Tanpa adanya sarana atau fasilitas tersebut, tidak akan mungkin penegak hukum menyerasikan peranan yang seharusnya dengan peranan yang aktual.

D. Faktor Masyarakat

Penegak hukum berasal dari masyarakat dan bertujuan untuk mencapai kedamaian di dalam masyarakat. Setiap warga masyarakat atau kelompok sedikit banyaknya mempunyai kesadaran hukum, persoalan yang timbul adalah taraf kepatuhan hukum, yaitu kepatuhan hukum yang tinggi, sedang, atau kurang. Adanya derajat kepatuhan hukum masyarakat terhadap hukum, merupakan salah satu indikator berfungsinya hukum yang bersangkutan.

Sikap masyarakat yang kurang menyadari tugas polisi, tidak mendukung, dan malahan kebanyakan bersikap apatis serta menganggap tugas penegakan hukum sematamata urusan polisi, serta keengganan terlibat sebagai saksi dan sebagainya. Hal ini menjadi salah satu faktor penghambat dalam penegakan hukum.

\section{E. Faktor Kebudayaan}

Dalam kebudayaan sehari-hari, orang begitu sering membicarakan soal kebudayaan. Kebudayaan menurut Soerjono Soekanto, mempunyai fungsi yang sangat besar bagi manusia dan masyarakat, yaitu mengatur agar manusia dapat mengerti bagaimana seharusnya bertindak, berbuat, dan menentukan sikapnya kalau mereka berhubungan dengan orang lain. Dengan demikian, kebudayaan adalah suatu garis pokok tentang perikelakuan yang menetapkan peraturan mengenai apa yang harus dilakukan, dan apa yang dilarang.

Kelima faktor di atas saling berkaitan dengan eratnya, karena menjadi hal pokok dalam penegakan hukum, serta sebagai tolok ukur dari efektifitas penegakan hukum. Dari lima faktor penegakan hukum tersebut faktor penegakan hukumnya sendiri merupakan 
titik sentralnya. Hal ini disebabkan oleh baik undang-undangnya disusun oleh penegak hukum, penerapannya pun dilaksanakan oleh penegak hukum dan penegakan hukumnya sendiri juga merupakan panutan oleh masyarakat luas.

Kelima faktor yang dikemukakan Soerjono Soekanto tersebut, tidaklah disebutkan faktor mana yang sangat dominan berpengaruh atau mutlaklah semua faktor tersebut harus mendukung untuk membentuk efektifitas hukum. Namun sistematika dari kelima faktor ini jika bisa optimal, setidaknya hukum dinilai dapat efektif.

Sistematika tersebut artinya untuk membangun efektifitas hukum harus diawali untuk mempertanyakan bagaimana hukumnya, kemudian disusul bagaimana penegak hukumnya, lalu bagaimana sarana dan fasilitas yang menunjang, kemudian bagaimana masyarakat merespon serta kebudayaan yang terbangun.

Dari apa yang dikemukakan Soerjono Soekanto, tentu bukan hanya kelima faktor tersebut, tetapi banyak faktor-faktor lainnya yang ikut mempengaruhi efektifnya suatu hukum diterapkan. Salah satu inisialnya adalah faktor keadaan atau kondisi yang melingkupi penerapan suatu hukum ${ }^{25}$

Penghukuman pelaku maisir di Kota Langsa, sebagaimana Legal subtance (substansi hukum) adalah berdasarkan Qanun Aceh Nomor 6 Tahun 2014 tentang Hukum Jinayat dan Qanun Aceh Nomor 7 Tahun 2013 tentang Hukum Acara Jinayat, dimana sebelumnya penghukumannya berdasarkan Qanun Aceh Nomor 13 Tahun 2003 tentang Maisir. Pelaku maisir rata rata disangka dan didakwa denganPasal 18 Qanun Aceh Nomor 6 Tahun 2014 tentang Hukum Jinayat yaitu: Setiap Orang yang dengan sengaja melakukan Jarimah Maisirdengan nilai taruhan dan/atau keuntungan paling banyak 2(dua) gram emas murni, diancam dengan 'Uqubat Ta'zir cambukpaling banyak 12 (dua belas) kali atau denda paling banyak 120(seratus dua puluh) gram emas murni atau penjara paling lama12 (dua belas) bulan. Dalam hal penghukuman bagi pelaku maisir diKota Langsa, putusan yang dijatuhkan terhadap terdakwa pelaku maisir adalah 'Uqubat Ta'zir yaitu cambuk sekitar 6 s/d 8 kali.

Proses peradilan dalam kasus maisir di Kota Langsa berdasarkanasas:proses peradilan menyeluruh, sederhana, cepat, dan biaya ringan yaitu Penangkapan, dapat dilakukan untuk paling lama 1 (satu) hari.Masa Penahanan untuk pelaku jarimah yang ancamanuqubatnya penjaranya paling lama 12 (dua belas) bulansebagaimana dimaksud pada ayat (1) berlaku ketentuansebagai berikut :

a. Penyidikan, paling lama 15 (lima belas) hari;

b. Penuntutan, paling lama 5 (lima) hari ;

c. Pemeriksaan pada Mahkamah Syar'iyah Kabupaten/Kota, paling lama 15 (lima belas) hari;

d. Pemeriksaan banding pada Mahkamah Syar'iyah Aceh, paling lama 20 (dua puluh) hari; dan

e. Pelaksanaan uqubat, paling lama 5 (lima) hari.

Legal Structure (struktur hukum) yaitu Qanun Hukum Acara Jinayat berlaku untuk lembaga penegak hukum dan setiap orang yang berada di Aceh.Penyelidik merupakan Pejabat Polri dan PPNS yang telah diberiwewenang oleh Undang-Undang dan/atau

${ }^{25}$ http://atsiwwista.blogspot.co.id/2013/09/teori-teori-efektivitas.html 
Qanun untukmelakukan penyelidikan.Penyidik terdiri atas: a. Pejabat Polri; danb. PPNS tertentu yang diberi wewenang khusus oleh Undang-undang dan/atau Qanun. Pangkat Penyidik Pejabat Polri, mengikuti ketentuan Kepolisian.PPNS,berpangkat paling rendah Penata Muda, Golongan III/a atauyang disamakan dengan itu. Jaksa adalah pejabat fungsional yang diberi wewenang olehundang-undang untuk bertindak sebagai penuntut umum danpelaksana putusan pengadilan yang telah memperolehkekuatan hukum tetap serta wewenang lain berdasarkanundang-undang. Penuntutan adalah tindakan penuntut umum untukmelimpahkan perkara jinayat ke Mahkamah Syar'iyah yangberwenang dalam hal dan menurut cara yang diatur dalamUndang-Undang dan/atau Qanun dengan permintaan supayadiperiksa dan diputuskan oleh hakim di sidang Mahkamah.Mahkamah Syar'iyah Kabupaten/Kota adalah lembagaperadilan tingkat pertama. Mahkamah Syar'iyah Aceh adalah lembaga peradilan tingkatbanding. Mahkamah Agung Republik Indonesia yang selanjutnyadisebut Mahmakah Agung adalah lembaga peradilan tingkatkasasi.Polisi Wilayatul Hisbah yang selanjutnya disebut Polisi WHadalah anggota WH yang berfungsi melakukan sosialisasi,pengawasan, penegakan dan pembinaan pelaksanaan SyariatIslam.

Legal culture (budaya hukum); dapat dilihat sebagaimana pada tabel berikut initerpidana pelaku maisir dari tahun-ketahun.

\begin{tabular}{|c|c|c|c|}
\hline Jenis Pidana & \multicolumn{3}{|c|}{ Kasus } \\
\hline \multirow{2}{*}{ Maisir } & 2015 & 2016 & 2017 \\
\cline { 2 - 4 } & 12 & 15 & 1 \\
\hline
\end{tabular}

Sumber data dari : Daftar Registrasi pada Bagian Arsip Mahkamah Syari'ah Langsa. ${ }^{26}$

Berdasarkan tabel tersebut, dapat dilihat dari hasil penelitian yang dilakukan kasus maisir pada setiap tahun tingkatannya mengalami naik turun. Pada tahun 2015 berjumlah 12 kasus, tahun 2016 berjumlah 15 kasus dan tahun 2017 berjumlah 1 kasus. Namun dari kasus tersebut tidak ada pelaku yang melakukan maisir kembali (residivis). Hal ini dapat dikatakan bahwa penghukuman pelaku maisir melalui 'uqubat ta'zir telah menimbulkan efek jera bagi para pelakunya.

Keberadaan hukuman, dalam filsafat penjeraan, adalah upaya menahan manusia untuk memilih penderitaan. Prinsip utiliti dari hukuman terletak pada kemampuannyamenciptakan rasa jera dalam diri pelaku untuk melakukan kejahatankembali di masa depan, dan rasa takut di masyarakat untuk melakukankejahatan serupa. Dalam rehabilitasi, prinsip utiliti dicapai denganmelakukan "modifikasi" pada diri pelaku kejahatan melalui program program intervensi. Demikian pula dengan reintegrasi, manfaat yang diberikan hukuman kepada pelaku kejahatan, selain "modifikasi" juga menjalinkan kembali hubungan yang terputus antara dirinya dengan masyarakat. ${ }^{27}$

Beberapa filsafat memandang tujuan penghukuman atau pidana sebagaibentuk pembalasan dan pemberi rasa takut atau efek pencegah (deterrent effect) bagiorang lain agar tidak melakukan kejahatan serupa di kemudian hari. Di sisi lain, adapula yang

${ }^{26}$ Obeservasi dan wawancara dengan Mahkamah Syar 'iyah Langsa

${ }^{27}$ Iqrak Sulhin, Filsafat (Sistem) Pemasyarakatan, Program Pascasarjana Filsafat Fakultas Ilmu Budaya, Universitas Indonesia, Jurnal Kriminologi Indonesia, Vol. 7 No.I Mei, 2010, hlm 144145 . 
memandang hukuman sebagai cara untuk memperbaiki dan memberi efekjera bagi si pelaku sehingga tidak mau lagi melakukan perbuatan serupa di kemudianhari. Menurut pandangan pertama, tujuan hukuman baru akan terwujud apabilapelaku kejahatan diganjar dengan hukuman yang setimpal dengan perbuatannya dansemakin berat hukuman akan semakin membuat orang takut melakukan kejahatan. ${ }^{28}$

Berdasarkan hasil penelitian, penghukuman bagi pelaku maisir(perjudian) di Kota Langsa telah mendekati keefektifan. Hal ini dapat dilihat dan dipahami sebagai berikut:

1. Penghukuman berdasarkan peraturan perundang-undangan yang berlaku diantaranya 'Uqubat Hudud dan Takzir.

2. Proses peradilan menerapkan asas cepat, sederhana dan biaya ringan

3. Ex Narapidana tidak mengulangi perbuatan yang sama (residivis).

4. Menimbulkan efek jerahanya bagi nara pidana dan sebahagian masyarakat di Kota Langsa dan tidak menutup kemungkinan selalu adanya pelaku baru.

5. Penegak hukum saling berkoordinasi dalam penegakan tidak pidana maisir.

6. Durasi masa hukuman yang singkat.

7. Menghemat pengeluaran negara.

\section{Hambatan penghukuman bagi pelaku maisir (perjudian) di Kota Langsa}

Permasalahan yang esensial dalam penegakan hukum di Indonesia bukan hanyasemata-mata terhadap produk hukum yang tidak responsif, melainkan juga berasal dari faktor aparat penegak hukumnya. Untuk meletakkan pondasi penegakan hukum, makapilar yang utama adalah penegak hukum yang mampu menjalankan tugasnya dengan integritas dan dedikasi yang baik.Tindak pidana maisir yang terjadi di Kota Langsatelah mendekati keefektifan. Akan tetapi, berdasarkan hasil penelitian, maka diketahui hambatan dalam penghukuman bagi pelaku maisir(perjudian) di Kota Langsa terdiri dari 2 faktor yaitu faktor penegak hukum dan faktor masyarakat sebagai berikut:

a. Faktor Penegak Hukum

1. Belum adanya sumber daya manusia dari WH yang berkapasitas/kompeten sebagai PPNS, sehingga belum dapat mandiri dalam melakukan penegakan hukum.

2. Terkadang tidak ada upaya pengejaran atau tidakan lebih lanjut oleh Penyidik dalam hal daftar pencarian orang (DPO) jika tersangka melarikan diri.

b. Faktor Masyarakat

Faktor masyarakat dan kebudayaan ini memegang peranan sangat penting, hal ini berkaitan dengan taraf kesadaran hukum dan kepatuhan hukum masyarakat. Kesadaran hukum merupakan suatu proses yang mencakup unsur pengetahuan hukum, pemahaman hukum, sikap hukum dan perilaku hukum. Tingkat kesadaran hukum tercapai apabila masyarakat mematuhi hukum.Belum adanya kesadaran / keinsyapan dari masyarakat untuk tidak melakukan maisir. Hal demikian dapat dilihat dari pelaku maisir yang masih ada setiap tahunnya terdiri dari segala jender pria dan wanita serta segala usia dewasa,

28 Mohammad, Hukuman Mati Dan Hak Asasi Manusia Dalam Peraturan PerundanganUndangan, Jurnal "Yustitia", Volume 12, No.1 Nop, 2011, hlm 7 
remaja dan anak-anak. Jikakesadaran hukum masyarakat tidak ada, maka dapat disandarkan dengan teori fungsi yang digunakan merupakan teori dari Kats (1960), dimana menurut Kats perilaku dilatarbelakangi oleh kebutuhan individu yang bersangkutan. Kats mengasumsikan 4 fungsi perilaku yaitu:

1. Perilaku memiliki fungsi instrumental, artinya perilaku dapat memberikan pelayananan terhadap kebutuhan. Seseorang dapat bertindak positif demi pemenuhan kebutuhannya, namun seseorang juga dapat bertindak negatif bila kebutuhannya tidak tercukupi.

2. Perilaku berfungsi sebagai defence mechanism atau sebagai pertahanan diri dalam menghadapi lingkungannya. Artinya dengan perilakunya individu dapat melindungi dirinya dari ancaman yang datang dar luar.

3. Perilaku berfungsi sebagai penerima objek dan pemberi arti, artinya tindakan yang dilakukan individu selalu berusaha untuk menerima dan menyesuaikan diri dengan lingkungannya. Proses tersebut menimbulkan tindakan-tindakan yang spontan dan dalam kurun waktu yang singkat.

4. Perilaku sebagai nilai ekspresif dari diri seseorang dalam menjawab situasi yang dihadapinya. Disini berarti perilaku yang dilakukan oleh seorang individu merupakan ungkapan dari apa yang sedang individu tersebut rasakan. ${ }^{29}$

Faktor kebutuhan inilah yang menyebabkan kesadaran dan kepatuhan akan hukum yang berlaku telah diabaikan oleh para pelaku maisir. Masyarakat tidak akan terjerumus kepada perbuatan maisir apabila, masyarakat lebih paham dan mengisyafi bahwa mudharat dari maisir itu lebih besar manfaatnya. Memenuhi kebutuhan berlimpah dengan cara instan cenderung akan membawa ke jalan pintas yang akibatnya akan merugikan diri sendiri, keluarga dan meresahkan masyarakat. Sehingga bersyukur, berusaha yang halal dan mempertebal keimanan adalah kuncinya untuk terhindar dari maisir.

\section{Penutup}

Berdasarkan hasil penelitian, penghukuman bagi pelaku maisir (perjudian) di Kota Langsa telah mendekati keefektifan. Hal ini dapat dilihat dan dipahami sebagai berikut:

1. Penghukuman berdasarkan peraturan perundang-undangan yang berlaku diantaranya 'Uqubat Hudud dan Takzir.

2. Proses peradilan menerapkan asas cepat, sederhana dan biaya ringan

3. Ex Narapidana tidak mengulangi perbuatan yang sama (residivis).

4. Menimbulkan efek jera hanya bagi nara pidana dan sebahagian masyarakat di Kota Langsa dan tidak menutup kemungkinan selalu adanya pelaku baru.

5. Penegak hukum saling berkoordinasi dalam penegakan tidak pidana maisir.

6. Durasi masa hukuman yang singkat.

7. Menghemat pengeluaran negara.

Tindak pidana maisir yang terjadi di Kota Langsa telah mendekati keefektifan. Akan tetapi, berdasarkan hasil penelitian, maka diketahui hambatan dalam penghukuman

${ }^{29}$ Kats, Teori Fungsi Perilaku, dalam Soekidjo Notoatmodjo, Ilmu Perilaku Kesehatan, (Jakarta : Rineka Cipta, 2010), hlm 86. 
bagi pelaku maisir(perjudian) di Kota Langsa terdiri dari 2 faktor yaitu faktor penegak hukum dan faktor masyarakat.

\section{Daftar Pustaka}

\section{Buku-Buku}

Abdul Azis Dahlan, Ensiklopedi Hukum Islam, PT Ichtiar Baru van Hoeve, Jakarta, 1999

Al Yasa' Abu bakar \& Mahar Halim, 2006, Hukum Pidana Islam di Nanggro Aceh Darussalam, Dinas syari' at Islam Provinsi NAD, Banda Aceh, 2006

Budaya, Universitas Indonesia, Jurnal Kriminologi Indonesia, Vol. 7 No.I Mei.

Burban Bungi, Analisis Data Penelitian Kualitatif, Pemahaman Filosofis Dan Metodologis Kearah Penguasaan Aplikasi, Raja Gravindo Persada, Jakarta, 2003

Iqrak Sulhin, Filsafat (Sistem) Pemasyarakatan, Program Pascasarjana Filsafat Fakultas Ilmu Filsafat, 2010

Kats, Teori Fungsi Perilaku dalam Soekidjo Notoatmodjo, Ilmu Perilaku Kesehatan, Rineka Cipta, Jakarta, 2010

Mohammad, Hukuman Mati Dan Hak Asasi Manusia Dalam Peraturan Perundangan Undangan, Fakultas Hukum Universitas MaduraPamekasan, Jurnal "Yustitia", Volume 12, No.1 Nop. 2011

Rusjdi Ali Muhammad dan Dedy Sumardi, Kearifan Tradisional Lokal Penyerapan Syariat Islam Dalam Hukum Adat Aceh, Dinas Syariat Islam Aceh, Banda Aceh, 2011

Sudarsono, Kamus Hukum, Rineka Cipta, Jakarta, 2007.

Zainuddin Ali, 2007, Hukum Pidana Islam, Cetakan I, Jakarta : Sinar Grafika.

\section{Peraturan perundang-Undangan}

Undang-Undang Dasar Negara Republik Indonesia Tahun 1945

Undang-Undang Nomor 11 Tahun 2006 tentang Pemerintahan Aceh

Qanun Aceh Nomor 7 Tahun 2013 tentang Hukum Acara Jinayat

Qanun Aceh Nomor 6 Tahun 2014 tentang Hukum Jinayat 
Volume 13, Nomor 1, Januari-Juni 2018

\section{Internet}

Sumber: http://www.ibn-jebreen.com/books/1-26-1162-1103-27973.html

http://kippas.wordpress.com/2007/06/04/euforia-pers-terhadap penerapan-syariatislam/ di akses tangga 20 Mei 2016. 